\title{
ЗАСЛУЖЕНОМУ ПРАЦІВНИКУ ОСВІТИ УКРАЇНИ, ЕПІДЕМІОЛОГУ ОЛЕКСАНДРУ ДАНИЛОВИЧУ КРУШЕЛЬНИЦЬКОМУ ВИПОВНИЛОСЯ 70 РОКІВ
}

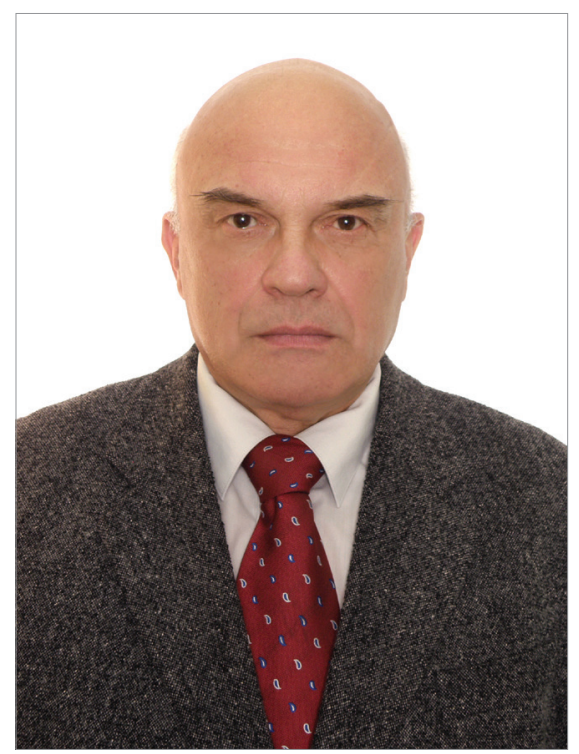

Стисло висвітлено основні біографрічні віхи й творчий доробок О.Д. Крушельницького - заслуженого працівника освіти України, лікаря-епідеміолога, кандидата медичних наук, доцента кафредри військово-профрілактичної медицини Української військово-медичної академії.

23 лютого 2020 р. виповнилося 70 років 3 дня народження Олександра Даниловича Крушельницького - досвідченого епідеміолога, кандидата медичних наук, доцента кафедри військово-профрілактичної медицини Української військово-медичної академії.

Олександр Данилович народився у м. Ашхабат (Туркменістан) в родині військовослужбовця та лікарки. Від батьків успадкував потяг до освіти і постійного оновлення знань та професійного удосконалення.

У 1967-1973 рр. навчався у Київському медичному інституті ім. О.О. Богомольця на санітарно-гігієнічному фракультеті. Отримавши диплом санітарного лікаря, за спрямуванням МО3, працював в Одеській і Житомирській областях. У1974-му був призваний на військову службу в окремий зенітно-ракетний дивізіон на посаду начальника медичного пункту-лікаря частини. Почалася звичайна служба військового лікаря. В 1976 р. після первинної спе- ціалізації з епідеміології в інтернатурі медичного складу був переведений в санітарно-епідеміологічний загін Київського військового округу (СЕЗ КВО). У 1983-му вступив на фракультет керівного медичного складу Ленінградської військово-медичної академії. Через два роки, отримавши диплом офріцера з вищою медичною освітою лікаря-епідеміолога, був призначений на посаду начальника гарнізонного санітарно-епідеміологічного загону в Ашхабат (Туркменія).

У 1987 р. згідно з поданим рапортом був переведений в м. Кундуз (Асрганістан) на посаду начальника санітарноепідеміологічного загону (CE3). Тоді санітарно-епідеміологічні установи на території Афганістану дислокувались у Кабулі, Кундузі, Шинданді, СКП - у Хайратоні. До штату CEЗ окремою директивою була додана пересувна санітарно-епідеміологічна лабораторія. Чисельність особового складу сягала 43 осіб: 13 офріцерів, 18 солдатів строкової служби, 12 службовців. Територія відповідальності охоплювала такі населені пункти: Кундуз (Північний та Південий), Пулі-Хумрі, Таш-Курган, а також шлях до північного порталу перевалу Саланг і в протилежному напрямку - до Хайратона і Файзабада. СЕЗ здійснювал кваліфіковані та спеціалізовані профілактичні та протиепідемічні заходи в обсязі, визначеному керівними документами та відповідно до обставин.

У серпні 1988 р. Кундузький СЕЗ було виведено на територію СРСР. Офріцери отримали нові призначення, солдати вибули до нових місць служби, службовці - до місць проживання або за бажанням. Все майно, обладнання, прибори залишились афрганській стороні відповідно 3 директивними вказівками та актами передачі. Начальник О.Д. Крушельницький відбув у СЕЗ КВО.

На початку 90-их разом з ресормуванням 3С почалась оптимізація санітарно-епідеміологічної служби МО України, отримання нею більшої самостійності. Був створений вищий військово-медичний навчальний заклад «Українська військово-медична академія (УВМА)». Саме туди із Центру державного санітарно-епідеміологічного нагляду (ЦДСЕН) перевели О.Д Крушельницького.

1 вересня 1993 р. Олександр Данилович розпочав викладання військової епідеміології, започаткувавши вивчення цієї дисципліни в УВМА, а згодом вперше в країні до- 
слідив протиепідемічне забезпечення військ України в мирний і воєнний час. У 1995 р. отримав звання полковника медичної служби. Протягом служби в академії обіймав посади викладача, старшого викладача, заступника відділу військово-профрілактичних досліджень наукового центру військової медицини. А з 2002 р. - доцент кафедри військово-профрілактичної медицини. Дисертацію на здобуття наукового ступеня кандидата медичних наук на тему «Протиепідемічне забезпечення військ України в умовах їх ресрормування на мирний та воєнний час» захистив у 1999 р., науковий керівник - доктор медичних наук, профресор А.М. Зарицький. Консультативну допомогу з окремих питань отримав від доктора медичних наук, професора М.І. Хижняка.

Вагоме науково-практичне значення, зокрема навчальне, мають наступні колективні роботи, які присвячені найбільш актуальним питанням епідеміології та видані за участю О.Д. Крушельницького:

- Військова епідеміологія з епідеміологією надзвичайних ситуацій: підручник. - Тернопіль, 2015.

- Біобезпека: практичний порадник. - Одеса, 2018.

- Епідеміологічні аспекти біобезпеки: Київ, 2019.

- Настанова з організації суворого протиепідемічного режиму у військово-медичних закладах (установах) Міністерства оборони України при роботі з особливо небезпечними інфрекційними захворюваннями та їх збудниками. - Київ, 2016.

- Епідеміологічне обстеження в осередках інфекційних хвороб у ЗС України в мирний та воєнний час: навчальний посібник. - Київ, 2019.

Наукові здобутки ювіляра широко висвітлені у 131 праці, серед яких п'ять підручників, дев'ять навчальних посібників, три монограсрії, три методичних рекомендації.
Високопрофесійно й натхненно доц. О.Д. Крушельницький читає лекції, майстерно проводить практичні заняття та семінари зі слухачами I та II фракультетів УВМА, сумлінно виконує обов'язки члена редакційної ради всеукраїнського науково-практичного медичного журналу «Інфекційні хвороби».

Колектив УВМА, численні колеги і друзі поважають й шанують Олександра Даниловича - талановитого науковця і педагога, висококвалісрікованого епідеміолога, за багаторічну невтомну працю, високий професіоналізм, сумлінне виконання своїх службових і громадських обов'язків й бажають ювіляру міцного здоров'я та нових творчих здобутків.

Колектив Української військово-медичної академії, редакція журналу «Інфекційні хвороби».

\section{HONORED WORKER OF EDUCATION OF UKRAINE, EPIDEMIOLOGIST OLEKSANDR DANYLOVYCH KRUSHELNYTSKYI IS 70 YEARS OLD}

SUMMARY. The main biographical milestones and creative achievements of $O$. D. Krushelnytskyi Honored Worker of Education of Ukraine, doctorepidemiologist, Candidate of Medical Sciences, Associate Professor of Military Preventive Medicine of the Ukrainian Military Medical Academy are briefly covered.

Конорлікту інтересів немає.

The authors have no conflicts of interest to declare. Отримано 23.08.2020 p. 